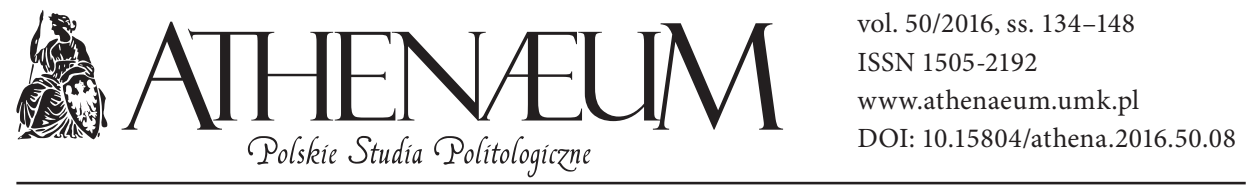

\title{
ROLA KOSOWA W BRYTYJSKIEJ POLITYCE ZAGRANICZNEJ PO ROZPADZIE JUGOSŁAWII
}

\author{
THE ROLE OF KOSOVO IN BRITISH FOREIGN POLICY AFTER \\ DISINTEGRATION OF THE YUGOSLAVIA
}

\author{
Bartłomiej H. Toszek*
}

\begin{abstract}
ABSTRAKT
Czynnikiem determinującym charakter stosunków brytyjsko-kosowskich jest ogromna dysproporcja potencjałów obu państw we wszystkich możliwych sferach. Nieposiadające pełnego uznania międzynarodowego, słabe pod względem ekonomicznym Kosowo nie może stanowić partnera dla Wielkiej Brytanii, dysponującej niekwestionowaną pozycją na płaszczyźnie gospodarczej, politycznej i militarnej. Nie znajduje się ono również w centrum zainteresowań brytyjskich, a wzajemne kontakty zostały nawiązane niejako przy okazji wypełniania przez Brytyjczyków „moralnego zobowiązania”, a nie na podstawie racjonalnych przesłanek. W tym kontekście obowiązująca formuła relacji opiera się na założeniu brytyjskiego paternalizmu, który wyraża się oddziaływaniem na kierunki aktywności politycznej oraz rozwój gospodarczy i społeczny Kosowa, a także występowaniem w obronie interesów Kosowa przed społecznością międzynarodową (w szczególności na forum Unii Europejskiej i NATO). Natomiast mieszkańcy Kosowa poprzez korzystanie $\mathrm{z}$ udzielanej przez Brytyjczyków na bieżąco pomocy wojskowej,
\end{abstract}

The main factor determining relations between the UK and Kosovo is huge disproportion of potential in all possible spheres. In comparison of strong British economic, political and military power Kosovo with its lack of full international recognition of its sovereignty and weak economy has no ability to be real partner for the UK. It is out of British interests circle either, because mutual contacts are created rather on moral obligation than real base. In consequence present relations formula gives the UK paternal role by possibility of shaping Kosovo's authorities decisions applied to both political and socioeconomic affairs. However this position is connected with obligation to represent Kosovo's interests before international community, especially in the EU and the NATO. Simultaneously Kosovars have a lot of advantages in co-operation with the UK as political, military and economic support and know-how in almost all spheres of public life, but in exchange they take out debt of gratitude which is difficult to appraise and repay. Anyway future membership of Kosovo in the EU and the NATO

* Uniwersytet Szczeciński, Instytut Politologii i Europeistyki. 
politycznej i finansowej oraz udostępnienie know-how zaciągnęli wobec Wielkiej Brytanii dług wdzięczności, którego spłata jest tym trudniejsza, że ani jej termin, ani warunki nie mają wymiaru formalnego. Nie ulega jednak wątpliwości, że w przypadku wejścia Kosowa do Unii Europejskiej i NATO istnieje spora szansa, że kosowscy politycy będą głosowali w tych organizacjach w sposób odpowiadający życzeniom brytyjskim. Dalekosiężna polityka Wielkiej Brytanii zmierzająca do pozyskania przyszłego sojusznika wewnątrz struktur europejskich wydaje się zatem przynosić pożądane efekty, służąc równocześnie stabilizacji i rozwojowi tej części Bałkanów Zachodnich.

Słowa kluczowe: stosunki międzynarodowe, integracja europejska, Wielka Brytania, była Jugosławia, Kosowo will make the UK stronger in these organizations, because there will be no doubts Kosovar's politicians will vote correct to the British wishes. The UK policy directed to gain future ally inside the European structures seems to be effective and simultaneously brings stabilization and development for this part of the Western Balkans.

Keywords: International relations, European integration, the United Kingdom, Former Yugoslavia, Kosovo

Nie ulega wątpliwości, że zaangażowanie Wielkiej Brytanii w proces kształtowania suwerenności Kosowa na płaszczyźnie militarnej i politycznej (uwieńczony nawiązaniem stosunków dyplomatycznych w 2008 r.) wykraczało poza standardowe ramy zainteresowań dyplomacji brytyjskiej sprawami europejskimi. Jest bowiem oczywiste, że odmienne uwarunkowania geopolityczne oraz wyraźna różnica potencjałów obu państw skazują na niepowodzenie wszelkie próby wypracowania formuły dwustronnych relacji opartych na zasadach partnerskich. Jaki był zatem sens podjęcia przez Brytyjczyków działań ukierunkowanych na wyodrębnienie nowego organizmu państwowego na obszarze Bałkanów Zachodnich? Czy działania te stanowiły rezultat przemyślanej koncepcji politycznej, mającej przynieść Wielkiej Brytanii długofalowe korzyści, czy też były prostą konsekwencją określonego splotu wydarzeń nieposiadających głębszego znaczenia, które nie wytworzyły trwałej podstawy do przyszłej brytyjsko-kosowskiej kooperacji? Aby udzielić odpowiedzi na tak postawione pytania, autor niniejszego artykułu dokonał analizy systemowej omawianego zagadnienia, posługując się również kontekstem historycznym i elementami analizy decyzyjnej.

Doktryna polityki zagranicznej Wielkiej Brytanii wobec narodów, a następnie państw bałkańskich ${ }^{1}$ została wypracowana dopiero w drugiej połowie XIX w. Do

1 Z wyjątkiem części Czarnogóry, zachowującej szeroką autonomię wewnętrzną przez okres panowania tureckiego, cały obszar Bałkanów (od pogranicza bośniacko-chorwackiego do południowych 
tego czasu obszary leżące między Dunajem a półwyspem peloponeskim były postrzegane przez Brytyjczyków po prostu jako część imperium osmańskiego. „Położenia uciemiężonych narodów chrześcijańskich na Bałkanach, a nawet samego ich istnienia, nie bardzo się domyślano [...]. Dlatego też nie wysunięto żadnej propozycji stworzenia wolnej Bułgarii i Serbii, ażeby w ten sposób zahamować rozszerzanie się wpływów rosyjskich" (Trevelyan, 1963, s. 772). Pomijając incydentalne zaangażowanie na rzecz niepodległości Grecji, będące rezultatem nie tyle chłodnej kalkulacji politycznej, co raczej oddziaływania na umysły brytyjskie romantycznej wizji Lorda Byrona², Wielka Brytania konsekwentnie występowała w obronie interesów tureckich we wszystkich sporach dyplomatycznych i konfliktach zbrojnych prowadzonych przez Wysoką Portę z Rosją. Te same założenia polityki europejskiej, które skłaniały Brytyjczyków do osłabiania ekspansji terytorialnej Francji w zachodniej części kontynentu, przyświecały im podczas wojny krymskiej, w której oddziały brytyjskie, francuskie i tureckie walczyły ramię w ramię przeciwko Rosjanom ${ }^{3}$. Istniejący stan rzeczy uległ zmianie w latach 1876-1878, kiedy prowadzona na forum Parlamentu Brytyjskiego dyskusja ${ }^{4}$ Benjamina Disraeliego ${ }^{5}$ i Williama Gladstone’ ${ }^{6}{ }^{6}$ „obudziła

krańców Peloponezu) został inkorporowany do imperium osmańskiego; do końca XVII w. W XIX w. niepodległość uzyskały kolejno: Grecja (w 1830 r.), Serbia, Rumunia i Czarnogóra (w 1878 r.), natomiast Bułgaria i Albania stały się suwerennymi państwami dopiero w XX w. (odpowiednio w latach 1908 i 1913).

2 Zob. szerzej: Beaton R. (2013), Byron's War: Romantic Rebellion, Greek Revolution, Cambridge: Cambridge University Press.

3 Zob. szerzej: Klimecki M. (2006), Krym 1854-1855, Warszawa: Dom Wydawniczy Bellona.

${ }^{4}$ Istotą sporu B. Disraeliego i W.E. Gladstone’a była odmienna interpretacja zasady równowagi sił (balance of powers) stanowiącej filar „polityki europejskiej” Wielkiej Brytanii w XIX w. Twórcą zasady był szkocki filozof, pisarz i historyk David Hume (1711-1776), który w pracy pt. „O równowadze sił” (On the balance of powers) opublikowanej w 1742 r. wskazywał na konieczność „utrwalania na kontynencie europejskim zasad liberalnych, które mogą zostać zrealizowane jedynie w warunkach pokoju [...]. Rola Wielkiej Brytanii sprowadza się więc do dążenia, aby w Europie mogły powstać właściwe warunki dla utrzymania odpowiedniej równowagi między rywalizującymi o pozycję dominującą $[\ldots]$ mocarstwami. Tego typu polityka nie wymaga bezpośredniej interwencji i angażowania się w sprawy europejskie, ale wystarczy, aby była ona oparta na odpowiedniej strategii polityczno-dyplomatycznej" (Gołembski, 2001, s. 12). W rzeczywistości zasada równowagi sił umożliwiała Wielkiej Brytanii zabezpieczenie swoich interesów w Europie, bez konieczności podejmowania interwencji zbrojnych.

${ }^{5}$ Benjamin Disraeli (1804-1881) - brytyjski polityk konserwatywny, zajmował stanowiska kanclerza skarbu w latach 1852, 1858-1859 i 1866-1868 oraz lorda Prywatnej Pieczęci w latach 1876-1878, był premierem Wielkiej Brytanii w latach 1868 i 1874-1880.

${ }^{6}$ William Ewart Gladstone (1809-1898) - brytyjski polityk liberalny, zajmował stanowiska podsekretarza stanu w ministerstwie wojny i kolonii w 1835 r., wiceministra i ministra handlu 
gwałtowne zainteresowanie ich rodaków sprawami politycznymi dotyczącymi bałkańskich wojen i rzezi. Gdyby nie wymowa tych dwóch genialnych mężów, sprawy te pozostałyby jakąś daleką bójką między wronami a krukami, wcale nie obchodzącą Anglii. Disraeli uczynił z rządu brytyjskiego głównego protektora Turków w Europie, jako tamy przeciwko wpływom rosyjskim; podczas gdy będący w opozycji Gladstone swą kampanią na temat 'bułgarskich okrucieństw $^{37}$ Turcji sprawił, że połowa opinii brytyjskiej przychylała się na stronę [...] narodów chrześcijańskich na Wschodzie" (Trevelyan, 1963, s. 811). Jednakże ani wahania nastrojów społecznych, ani nawet odwrócenie systemu sojuszy europejskich (wynikające $z$ utworzenia Trójprzymierza i Trójporozumienia) nie spowodowało zasadniczych zmian brytyjskiej polityki zagranicznej wobec tych części Turcji, które pozostawały bezpośrednio narażone na ekspansję rosyjską. Podczas działań wojennych w latach 1914-1918 front zachodni „nie był jedynym i być może najważniejszym teatrem wojny dla Anglii. Poważne znaczenie miał dla niej Bliski Wschód, gdzie sukcesy armii rosyjskiej w wojnie z Turcją naruszały angielskie wpływy na tym terenie" (Zins, 1995, s. 320). Ponadto w 1915 r. oddziały brytyjskie i francuskie dokonały desantu w rejonie Salonik, otwierając nowy front na Bałkanach, a tym samym dobitnie wskazując na zainteresowanie Wielkiej Brytanii i Francji tym obszarem.

Po I wojnie światowej zwycięskie mocarstwa europejskie stanęły przed koniecznością zaspokojenia różnych i niejednokrotnie wykluczających się wzajemnie roszczeń poszczególnych narodów i państw. Za podstawowe kryterium tworzenia nowego ładu politycznego przyjęto zasadę samostanowienia (zamiast formalnie obowiązującej od 1815 r. zasady legitymizmu), „, choć bardziej z czystej desperacji i pod naciskiem wydarzeń, niż z głębokiego przekonania. Anglicy i Francuzi [...] nie mieli planu radzenia sobie z rozpadającymi się imperiami i jednoczenia nowych organizmów państwowych ponad dotychczasowymi granicami” (Pavlowitch, 2009, s. 271). A jednak to właśnie Wielka Brytania i Francja zadecydowały w większości przypadków, „komu należy się samostanowienie i w jakim stopniu. W procesie tym ulegały ograniczeniom i wpływom poza-

w latach 1841-1843 i 1843-1845, ministra wojny i kolonii w latach 1845-1846, kanclerza skarbu w latach 1852-1855, 1859-1866, 1873-1874 i 1880-1882, lorda wysokiego komisarza Wysp Jońskich w 1859 r., lorda Prywatnej Pieczęci w latach 1886 i 1892-1894; był premierem Wielkiej Brytanii w latach 1868-1874, 1880-1885, 1886 i 1892-1894.

7 Zob. szerzej: Gladstone W.E. (1876), Bulgarian horrors and the question of the East, New York: Lovell, za: University of Toronto Libraries (2015), Bulgarian horrors and the question of the East (1876), http://archive.org/stream/bulgarianhorrors01gladuoft\#page/n1/mode/2up. 
merytorycznym. [...] Nowe organizmy musiały być wiarygodne i odpowiadać sposobowi pojmowania przez istniejące mocarstwa własnego bezpieczeństwa i własnych interesów" (Pavlowitch, 2009, s. 271).W ten sposób powstały państwa dysponujące wprawdzie ograniczonym potencjałem militarnym, politycznym i ekonomicznym, lecz równocześnie niezagrożone interwencją ze strony uwikłanej w wewnętrzne problemy i izolowanej na arenie międzynarodowej Rosji Radzieckiej, co odpowiadało brytyjskiej wizji ładu politycznego panującego w tej części Europy. W rezultacie Wielka Brytania, począwszy od 1920 r., ograniczyła swoją aktywność polityczną na Bałkanach, pozostawiając rolę mocarstwa na tym obszarze Francji.

Po raz kolejny Brytyjczycy zaangażowali się w problemy bałkańskie podczas II wojny światowej, co wyrażało się nie tylko bezpośrednim udziałem oddziałów brytyjskich w kampanii greckiej w 1941 r., obronie Dodekanezu i otwarciu frontu południowo-wschodniego w ostatniej fazie działań wojennych, lecz także udzielaniem stałego wsparcia ruchowi partyzanckiemu w Jugosławii i Grecji oraz udzieleniem schronienia władzom obu tych państw ${ }^{8}$. Ponieważ jednak w wyniku ustaleń przyjętych na konferencjach pokojowych w Jałcie i Poczdamie odnośnie podziału wpływów mocarstw zachodnich i Związku Radzieckiego w Europie, Jugosławia znalazła się po wschodniej stronie żelaznej kurtyny, stąd „brytyjska pomoc wojskowa dla jugosłowiańskiego ruchu oporu nie przyniosła spodziewanych [...] efektów" (Łastawski, 1979, s. 36) w postaci doraźnego lub trwałego umocnienia pozycji Wielkiej Brytanii w zachodniej części Bałkanów. Dodatkowo relacje obu państw ochłodziły się po odrzuceniu przez głównodowodzącego wojsk alianckich we Włoszech marszałka Harolda Alexandra9 możliwości zaspokojenia jugosłowiańskich roszczeń terytorialnych wobec Triestu ${ }^{10}$. W rezultacie stosunki brytyjsko-jugosłowiańskie na okres niemal 50 lat przybrały tę samą

8 Zob. szerzej: Nowakowski T., Skotnicki M. (1993), Kreta'41, Białystok: Altair; Solarz J. (2001), Bałkany 1940-1941, Warszawa: Wydawnictwo Militaria; Tanty M. (2009), Bałkany w XX w., Warszawa: Wydawnictwo Książka i Wiedza, s. 231-248; „Bitwa za Bałkany: Bojewyje diejstwija w Jużnoj Jewropie 28 oktiabria 1940-1 ijunia 1941 goda”, I. Moszczanskij (2007, „Wojennaja Lietopis”, nr 2, s. 40-51.

${ }^{9}$ Harold Rupert Leofric George Alexander (1891-1969) - brytyjski marszałek polowy, dowódca 1 korpusu Armii Brytyjskiej w 1940 r., dowódca zgrupowań armijnych w Anglii i na Bliskim Wschodzie w latach 1940-1942 i 1942-1943, zastępca dowódcy i dowódca kwatery głównej wojsk alianckich we Włoszech w latach 1943-1944 i 1944-1945, gubernator Kanady w latach 1946-1952, minister obrony w latach 1952-1954.

10 Zob. szerzej: Moro D., Refugees from the Eastern provinces of Italy after 1943, w: Bramwell A.C. (ed.) (1988), Refugees in the Age of Total War, London - Winchester (MA) - North Sydney - Wellington: Unwin Hyman, s. 138. 
płytką formułę, jaką miały kontakty wszystkich krajów socjalistycznych z najważniejszymi członkami bloku zachodniego.

Postępujący od 1991 r. systematyczny rozpad Jugosławii ${ }^{11}$ wywołał szereg nakładających się na siebie konfliktów o podłożu etnicznym i religijnym, które ze względu na swój gwałtowny i dramatyczny przebieg skłoniły społeczność międzynarodową do podjęcia interwencji wojskowej (pod auspicjami ONZ i NATO) w Bośni i Hercegowinie w latach 1992-1995 oraz w Kosowie w 1999 r. Wśród państw domagających się najbardziej zdecydowanych działań znajdowała się Wielka Brytania, która „w przypadku bośniackim aktywnie włączyła się do współuczestnictwa w międzynarodowych siłach zbrojnych (SFOR). Również w przypadku interwencji w Federacyjnej Republice Jugosławii w obliczu konfliktu w Kosowie opowiedziała się jednoznacznie za podjętymi działaniami zbrojnymi, uczestnicząc następnie w międzynarodowych siłach zbrojnych (KFOR)" (Gołembski, 2001, s. 104). Akcja militarna mająca położyć kres powtarzającym się aktom ludobójstwa dokonywanym przez złożoną z Albańczyków Armię Wyzwolenia Kosowa (Ushtria Çlirimtare e Kosovës), serbskie siły porządkowe oraz regularną armię jugosłowiańską została potraktowana przez władze brytyjskie jako swego rodzaju moralne zobowiązanie. Zdaniem ówczesnego premiera Wielkiej Brytanii Tony’ego Blaira ${ }^{12} \mathrm{w}$ taki sposób „powinno postąpić każde oświecone państwo, działające we własnym interesie. [...] Gdybyśmy pozwolili temu wrzodowi na ciele Europy dalej ropieć, nie sprzeciwiając się w żaden sposób czystkom etnicznym, to wkrótce ta zaraza objęłaby cały kontynent" (Blair, 2011, s. 324). Przeforsowane przez Brytyjczyków podjęcie (a następnie intensyfikacja) nalotów sił powietrznych NATO na jugosłowiańskie obiekty strategiczne znajdujące się poniżej 44 równoleżnika ${ }^{13}$ przyniosły spodziewany rezultat $\mathrm{w}$ postaci podjęcia rozmów pokojowych, które zakończyły się zawarciem prowizorycznego porozumienia w Kumanovie w czerwcu 1999 r. Wycofanie sił rządowych i wkroczenie oddziałów KFOR, a następnie utworzenie tymczasowej administracji wojskowej i cywilnej ONZ (United Nations Interim Administration Mission in Kosovo) ${ }^{14}$

${ }_{11}$ Zob. szerzej: Waldenberg M. (2003), Rozbicie Jugosławii, Warszawa: Wydawnictwo Naukowe Scholar.

12 Anthony „Tony” Charles Lyndon Blair (1953-) - brytyjski polityk laburzystowski, był premierem Wielkiej Brytanii w latach 1997-2007.

13 Zob. szerzej: Marszałek M. (2009), Sojusznicza operacja „Allied Force”: przebieg - ocena - wnioski, Toruń: Dom Wydawniczy Duet.

14 Zob. szerzej: UNHCR. The UN Refugee Agency (2015), Security Council resolution 1244 (1999) [on the deployment of international civil and security presences in Kosovo], http://www.refworld.org/ cgi-bin/texis/vtx/rwmain?docid=3b00f27216. 
nie oznaczało jednak zmiany statusu prawnomiędzynarodowego Kosowa, które pozostawało częścią Jugosławii. Aby zapobiec odnowieniu konfliktu między Serbami i Albańczykami w przyszłości, państwa biorące udział w operacji wojskowej i stanowiącej jej kontynuację misji stabilizacyjnej ONZ (w tym Wielka Brytania) podjęły decyzję o wspieraniu odśrodkowych ruchów separatystycznych. W tych warunkach miejscowe władze (istniejące od $2001 \mathrm{r}$.) pozostawały de facto niezależne od prezydenta Slobodana Miloševića ${ }^{15}$, co ostatecznie umożliwiło im jednostronne ogłoszenie niepodległości Kosowa w dniu 17 lutego 2008 r. Już następnego dnia deklaracja ta została uznana przez władze brytyjskie za wiążącą, czego naturalną konsekwencją stało się nawiązanie stosunków dyplomatycznych przez oba państwa, wyrażające się otwarciem ambasady Wielkiej Brytanii w Prisztinie w marcu 2008 r. oraz ambasady kosowskiej w Londynie siedem miesięcy później. Ponadto „do nowopowstałego państwa bałkańskiego został skierowany brytyjski kontyngent wojskowy [...] liczący ok. 600 żołnierzy mających stanowić gwarancje utrzymania porządku publicznego" (Norton-Taylor, 2008).

Po wyborach parlamentarnych w maju 2010 r., rządzących w Wielkiej Brytanii nieprzerwanie od 1997 r. laburzystów zastąpiła konserwatywno-liberalna koalicja pod przewodnictwem Davida Camerona ${ }^{16}$. Nowy premier odrzucił wypracowaną przez swoich poprzedników (tj. T. Blaira i Gordona Browna ${ }^{17}$ ) koncepcję polityki opierającej się na założeniu wyjątkowego i partnerskiego charakteru powiązań krajów wchodzących w skład Unii Europejskiej i pozostających w orbicie bezpośrednich wpływów tej organizacji. Kreśląc własną wizję stosunków panujących w Europie, wskazał na konieczność „skierowania uwagi nie tylko do wewnątrz, lecz także na inne części świata [...], a także zastąpienia sztywnej struktury skoncentrowanej na obronie osiągniętych pozycji przez sieć elastycznych, odpowiadających wymogom współczesnego świata, powiązań kształtowanych i umacnianych w formie dwustronnych relacji jedynie wspomaganych działaniami instytucji europejskich" (Harvey, 2011, s. 17). W ten sposób D. Cameron wyraził zamiar powrotu do tradycyjnego modelu polityki zagranicznej, bazującego na przekonaniu, że pozycja

15 Slobodan Milošević (1941-2006) - polityk serbski i jugosłowiański, był prezydentem kraju związkowego Serbii w latach 1989-1997 i prezydentem Jugosławii w latach 1997-2000.

${ }^{16}$ David William Donald Cameron (1966-) - brytyjski polityk konserwatywny, objął stanowisko premiera Wielkiej Brytanii w $2010 \mathrm{r}$.

17 James Gordon Brown (1951-) - brytyjski polityk laburzystowski, zajmował stanowisko kanclerza skarbu w latach 1997-2007, był premierem Wielkiej Brytanii w latach 2007-2010. 
Wielkiej Brytanii na płaszczyźnie międzynarodowej pozostaje uzależniona od równomiernego zaangażowania w stosunkach postimperialnych, atlantyckich i europejskich. A ponieważ ten ostatni kierunek był szczególnie faworyzowany w okresie sprawowania rządów przez T. Blaira i G. Browna, zatem konieczne stało się ograniczenie brytyjskiej obecności w Europie w wymiarze ekonomicznym, politycznym i militarnym. Z kolei podkreślenie znaczenia bilateralnej formuły budowania powiązań wewnątrzeuropejskich było równoznaczne z zakwestionowaniem potrzeby zacieśniania Wspólnej Polityki Zagranicznej i Bezpieczeństwa do stopnia krępującego swobodę samodzielnego kształtowania polityk zagranicznych przez państwa członkowskie UE. Podobne stanowisko wyraził również szef brytyjskiej dyplomacji William Hague podczas konferencji prasowej w lipcu 2010 r., wskazując, że „to dwustronne [a nie wielostronne] relacje służą umocnieniu naszej gospodarki, możliwości wpływania na sytuację na świecie oraz ochrony bezpieczeństwa [...], decydując o skuteczności naszych działań podejmowanych w strukturach międzynarodowych - UE, G20, czy Radzie Bezpieczeństwa ONZ" (Harvey, 2011, s. 16). Całkowite odrzucenie wytworzonej wewnątrz Unii Europejskiej koncepcji partnerstwa wszystkich państw członkowskich (poprzez konsekwentne wdrożenie zasady bilateralnego kształtowania wzajemnych relacji) otworzyłoby przed Wielką Brytanią perspektywę wchodzenia w interakcje o charakterze nie tylko de iure, ale także de facto partnerskim $\mathrm{z}$ dowolnie wybranymi podmiotami prawa międzynarodowego, dysponującymi co najmniej zbliżonym potencjałem ekonomicznym, politycznym lub militarnym. W tym kontekście niewielkie możliwości Kosowa na wszystkich wskazanych płaszczyznach musiały stanowić dla rządu D. Camerona przesłanki determinujące negatywną ocenę potencjalnej współpracy jako niedającej żadnych wymiernych korzyści.

Ostatecznie brytyjsko-kosowskie relacje przybrały po 2010 r. nierównomierną formułę, w której poziom aktywności Wielkiej Brytanii wyznacza wyłącznie dbałość o własne interesy. W wymiarze obejmującym działania militarne i twarde działania polityczne wszelkie przedsięwzięcia zostały niemal całkowicie zamrożone, o czym świadczy systematyczne zmniejszanie brytyjskiego kontyngentu w siłach KFOR (z 19000 w 1999 r. do 1 w 2013 r.) (NATO, 2014) oraz niepodejmowanie przez Ministerstwo Spraw Zagranicznych i Wspólnoty Narodów (Foreign and Commonwealth Office, FCO) jakichkolwiek stanowczych akcji na rzecz mieszkańców Kosowa. Równolegle jednak rząd Wielkiej Brytanii kilkukrotnie wywierał miękkie naciski polityczne na władze serbskie, np. w sprawie wycofania projektu rezolucji dotyczącej statusu prawnego Kosowa 
(złożonego w Zgromadzeniu Ogólnym ONZ w lipcu 2010 r.) ${ }^{18}$ oraz zawarcia porozumienia normalizującego stosunki serbsko-kosowskie (podpisanego ostatecznie w kwietniu 2013 r.) ${ }^{19}$. Premier i pozostali członkowie rządu brytyjskiego składali również publiczne deklaracje dotyczące poparcia kosowskich dążeń w sprawie przyłączenia do Unii Europejskiej i NATO. W liście gratulacyjnym skierowanym do Hashimiego Thaçiego ${ }^{20} \mathrm{z}$ okazji ponownego objęcia stanowiska szefa rządu kosowskiego, D. Cameron wyraził przekonanie, że „przyszłość Kosowa jest uzależniona od włączenia się w procesy integracji europejskiej [...], a urzeczywistnienie tego celu powinno być podstawowym założeniem współpracy naszych rządów" (UNIMIK, 2011). Również na oficjalnej stronie rządu brytyjskiego została umieszczona informacja o zamiarze wspierania ( $\mathrm{w}$ formie działań bezpośrednich oraz podejmowanych $\mathrm{w}$ porozumieniu $\mathrm{z}$ instytucjami Unii Europejskiej) wysiłków władz kosowskich „zmierzających do utrwalenia niepodległości i spoistości państwa, [...] zapewnienia jego zróżnicowanej pod względem kulturowym ludności poczucia stabilności i należytych warunków rozwoju, jako czynników stanowiących podstawę przybliżenia [...] członkostwa w strukturach UE i NATO” (UK Government, 2015, Policy...). Wypełnieniem tych deklaracji było skierowanie do Kosowa grupy ekspertów mających określić kierunki i metody demokratyzacji (w szczególności poprzez wytworzenie systemu należytej ochrony praw człowieka oraz praw mniejszości narodowych i etnicznych) i prywatyzacji, zachęcenie brytyjskich przedsiębiorców do otwierania swoich firm oraz inwestowania na terenie Kosowa, a także wprowadzenie sędziów do stałego składu Międzynarodowego Trybunału Karnego dla byłej Jugosławii ${ }^{21}$ (rozpatrującego m.in. sprawy dotyczące zbrodni wojennych doko-

18 Zob. szerzej: „Even Hague cannot convince Belgrade to withdraw resolution (dailies)”, 2010, UNMIK. Media monitoring. Kosovo Media Highlights, s. 1; Szpala M. (2015), Serbia pod presja Unii Europejskiej w sprawie Kosowa, http://www.osw.waw.pl/pl/publikacje/analizy/2010-09-15/ serbia-pod-presja-unii-europejskiej-w-sprawie-kosowa.

19 Zob. szerzej: TVN24 (2014), Serbia normalizuje stosunki z Kosowem. Jest bliżej Unii, http://www. tvn24.pl/wiadomosci-ze-swiata,2/serbia-normalizuje-stosunki-z-kosowem-jest-blizej-unii,320211. html; United Kingdom Government (2015), Foreign Secretary welcomes agreement between Kosovo and Serbia, https://www.gov.uk/government/news/foreign-secretary-welcomes-agreement -between-kosovo-and-serbia.

20 Hashim Thaçi (1968-) - polityk kosowski, jeden z przywódców Armii Wyzwolenia Kosowa (Ushtria Çlirimtare e Kosovës), przewodniczący Demokratycznej Partii Kosowa (Partia Demokratike e Kosovës) od 2004 r., pełni funkcję premiera Kosowa od 2008 r.

${ }^{21}$ Wielką Brytanię w Międzynarodowym Trybunale Karnym dla byłej Jugosławii reprezentowało 3 sędziów, tj. Richard May (1997-2004), Iain Bonomy (2004-2009) oraz Howard Morrison (od 2009 r.). 
nanych na terenie Kosowa $)^{22}$. Z perspektywy mieszkańców Kosowa największe znaczenie w kontaktach $\mathrm{z}$ Wielką Brytanią miał jednak wymiar finansowy, wyrażający się otrzymywaniem środków pomocowych z ogólnej puli $10 \mathrm{mln}$ GBP (pozostających w dyspozycji resortów spraw zagranicznych, obrony i rozwoju międzynarodowego), przeznaczonych na utrzymanie brytyjskiego kontyngentu w ramach operacji pokojowej EUFOR Althea prowadzonej przez Unię Europejską na obszarze Bośni i Hercegowiny (od momentu zakończenia misji SFOR przez NATO w grudniu 2004 r.), wspieranie działań Międzynarodowego Trybunału Karnego dla byłej Jugosławii mających na celu ukaranie winnych masakry w Srebrenicy ${ }^{23}$ oraz zbrodni wojennych w Kosowie, a także stworzenie warunków umożliwiających uchodźcom kosowskim powrót do ojczyzny. Ponadto FCO wyasygnowało kwotę ok. 3 mln GBP z przeznaczeniem na reformę administracji publicznej, systemów prawnych (w tym wytworzenie skutecznych metod zwalczania przestępczości zorganizowanej i korupcji) oraz transformacji gospodarczej Albanii, Bośni i Hercegowiny, Czarnogóry, Kosowa, Macedonii, Serbii i Turcji (UK Government, 2015, UK...). W rzeczywistości głównym celem programów pomocowych jest „umacnianie pozycji Wielkiej Brytanii na obszarach Bałkanów Zachodnich i Turcji, poprzez promowanie brytyjskich wartości i wpływów dyplomatycznych" (FCO, 2011). A ponieważ wszystkie państwa powstałe po rozpadzie Jugosławii (leżące na południe od Chorwacji) ubiegają się lub deklarują zamiar ubiegania się o członkostwo w strukturach Unii Europejskiej i NATO, to nawet stosunkowo skromne dofinansowanie przebiegających w nich procesów stabilizacji politycznej i dynamizacji rozwoju gospodarczego, pozwala Brytyjczykom sądzić, iż w ten sposób pozyskują przyszłych sojuszników w obu organizacjach międzynarodowych. Równocześnie wdrożenie efektywnych

${ }^{22}$ Zob. szerzej: UK Government (2015), Human Rights and Democracy Report launch, https:// www.gov.uk/government/news/2012-annual-human-rights-and-democracy-launch;UK Government (2015), Improving human rights in Kosovo, https://www.gov.uk/government/priority/improving-human-rights-in-kosovo; UK Government (2015), Joint embassy statement on Post \& Telekom of Kosovo privatisation, https:/www.gov.uk/government/world-location-news/joint-embassy-statementon-post-telekom-of-kosovo-privatisation; UK Government (2015), Increasing business with the Republic of Kosovo, https://www.gov.uk/government/priority/increasing-business-with-the-republic-of-kosovo; UK Government (2015), Supporting British nationals in Kosovo, https://www.gov.uk/ government/priority/supporting-british-nationals-in-kosovo.

${ }^{23}$ Masakra w Srebrenicy to określenie masowych egzekucji dokonanych w dniach 12-16 lipca 1995 r. przez oddziały serbskie na ok. 8000 muzułmańskich chłopców i mężczyzn w okolicach miasta Srebrenica, które zostały uznane za największe ludobójstwo w Europie od czasu II wojny światowej. 
programów zwalczania zorganizowanej przestępczości powoduje ograniczenie zjawiska emigracji zarobkowej, w tym nielegalnego podejmowania zatrudnienia na terenie Unii Europejskiej. W tym kontekście poprawa sytuacji politycznej i ekonomicznej na Bałkanach Zachodnich została uznana przez FCO za „swoisty sprawdzian umiejętności kształtowania przez UE kontaktów ze swoimi najbliższymi sąsiadami” (FCO, 2011).

Pomimo deklaracji przedstawicieli rządu brytyjskiego wskazujących na potrzebę pogłębienia i rozszerzenia zakresu współpracy Wielkiej Brytanii i Kosowa stosunki łączące oba państwa utrzymują niezmienny charakter od 2008 r. Podsumowując istniejący stan rzeczy w artykule opublikowanym na łamach internetowego wydania „Diplomat Magazine” we wrześniu 2011 r., kosowski wiceminister spraw zagranicznych Petrit Selimi ${ }^{24}$ stwierdził realistycznie, że „sukces brytyjskiej polityki na Bałkanach to stabilny region zintegrowany z UE i NATO [...], co zresztą leży również w interesie Kosowa, z powodów bardziej oczywistych [niż w przypadku Wielkiej Brytanii]. Czy później Wielka Brytania zapomni o Kosowie, bądź czy Kosowo zapomni o Wielkiej Brytanii? Z pewnością, nie. Wzajemne stosunki zintensyfikują się i staną się bardziej zróżnicowane. Będziemy jednym z wielu członków UE stojących po stronie Wielkiej Brytanii (podobnie jak ona po naszej) w sprawach dotyczących wszystkich aspektów życia publicznego [...]. Relacje ekonomiczne ukształtują nie tyle działania rządowe, co raczej kontakty indywidualnych przedsiębiorców oraz odbiorców ich towarów i usług [...]. Mamy również nadzieję, że nadal będą się rozwijały nasze kontakty kulturalne, które zostały nawiązane bezpośrednio po zakończeniu działań wojennych: przecież pierwszym przedstawieniem wystawionym w Kosowskim Teatrze Narodowym był szekspirowski „Hamlet” w reżyserii Davida Gotharda ${ }^{25}$, a słynny brytyjski zespół Morcheeb $a^{26}$ dał pamiętne wystąpienie w ubiegłym roku w Prisztinie. [...] Stosunki międzynarodowe stanowią sumę indywidualnych kontaktów ludzi zamieszkujących w różnych krajach. Takie kontakty między Wielką Brytanią a Kosowem nieustannie się rozwijają. Jako przykład można wskazać kosowskich studentów na uczelniach brytyjskich, których liczba jest wprawdzie niewielka, ale z roku na rok coraz większa. [...] Natomiast Brytyj-

${ }^{24}$ Petrit Selimi (1979-) - kosowski dziennikarz i polityk, jest wiceministrem spraw zagranicznych Kosowa od $2011 \mathrm{r}$.

${ }^{25}$ David Gothard jest znanym brytyjskim reżyserem i producentem teatralnym i filmowym.

${ }^{26}$ Morcheeba to występujący od 1995 r. brytyjski zespół wykonujący muzykę z pogranicza trip-hopu, rocka, folk-rocka, popu oraz tzw. muzyki dorosłego słuchacza (adult contemporary). 
czycy, tacy jak publicysta Christopher Hitchens ${ }^{27}$, historyk Noel Malcolm ${ }^{28}$, polityk Denis MacShane ${ }^{29}$, aktywistka na rzecz praw człowieka Bianca Jagger ${ }^{30}$, czy generał Sir Mike Jackson ${ }^{31}$, poprzez rozwijanie swoich zainteresowań związanych z Kosowem i ich propagowanie w Internecie, zwracają uwagę rosnącej liczby osób na charakter relacji łączących oba państwa. Ponadto Wielka Brytania i Kosowo zawarły ostatnio porozumienie dotyczące rozbudowania wzajemnych kontaktów środowisk kulturalnych, dyplomatycznych i akademickich za pośrednictwem [...] British Council. Nasza przyjaźń będzie więc kontynuowana, pogłębiana i rozszerzana na kolejne sfery życia publicznego" (Selimi, 2014).

Czynnikiem determinującym charakter stosunków brytyjsko-kosowskich jest ogromna dysproporcja potencjałów obu państw we wszystkich możliwych

${ }^{27}$ Christopher Eric Hitchens (1949-2011) - brytyjski pisarz, dziennikarz i krytyk literacki, publikujący swoje teksty w wielu opiniotwórczych magazynach brytyjskich i amerykańskich, m.in.: Free Inquiry, New Statesman, The Atlantic, The London Review of Books, The Nation, The Times Literary Supplement, The Wall Street Journal oraz Vanity Fair; był autorem ponad 20 książek poświęconych współczesnym wydarzeniom politycznym i kwestiom religijnym. „Hitchens napisał wiele listów, reportaży i felietonów poświęconych Kosowu dla liczących się magazynów, począwszy od Vanity Fair i The Washington Post, a skończywszy na periodykach zachodnioeuropejskich, na łamach których podjął polemikę [...] dotyczącą podstaw wojny w Kosowie. [...] Martwił się, że Clinton przekona premiera Blaira do wypracowania w ramach porozumienia NATO i Rosji kompromisowego rozwiązania podziału Kosowa i uznania sprawy jego albańskich mieszkańców za niegodną uwagi” (Selimi, 2015).

${ }^{28}$ Noel Malcolm (1956-) - brytyjski dziennikarz (publikujący swoje teksty na łamach Daily Telegraph i The Spectator do 1995 r.), pisarz i historyk, autor kontrowersyjnej „Krótkiej Historii Kosowa” (wydanej w 1998 r.).

${ }^{29}$ Denis MacShane (1948-) - były brytyjski polityk laburzystowski, był parlamentarnym podsekretarzem stanu w ministerstwie spraw zagranicznych i Wspólnoty Narodów odpowiedzialnym za sprawy Bałkanów i Ameryki Łacińskiej w latach 2001-2002 oraz ministrem stanu ds. europejskich w latach 2002-2005, jest autorem książki „Dlaczego Kosowo wciąż jest ważne?” (Why Kosovo still matters?) wydanej w $2011 \mathrm{r}$.

${ }^{30}$ Bianca Jagger (1945-) - brytyjska modelka, aktorka, działaczka na rzecz praw człowieka, jest ambasadorem dobrej woli Rady Europy, założycielką i przewodniczącą Fundacji Bianki Jagger na rzecz Praw Człowieka (Bianca Jagger Human Rights Foundation), członkiem Rady Zarządzającej amerykańskiej Amnesty International; w wygłaszanych publicznie oświadczeniach, artykułach prasowych, programach radiowych i telewizyjnych oraz na forach internetowych wielokrotnie domagała się rozliczenia winnych zbrodni wojennych i zbrodni ludobójstwa popełnionych na obszarach postjugosłowiańskich.

${ }^{31}$ Michael David „Mike” Jackson (1944-) - brytyjski emerytowany generał, był dowódcą wielonarodowej dywizji wykonującej na terenie Bośni i Hercegowiny misję pokojową w ramach sił IFOR w latach 1995-1996, głównodowodzącym korpusu sił szybkiego reagowania NATO w latach 1997-2000, głównodowodzącym brytyjskich sił lądowych w latach 2000-2003 oraz szefem brytyjskiego sztabu generalnego w latach 2003-2006. 
sferach. Wielka Brytania, zamieszkała przez ponad 63,18 mln ludności (wg danych z 2011 r.) zajmuje pod względem zaludnienia 22 miejsce w skali globalnej (ONS, 2015). Jest krajem wysokorozwiniętym, którego innowacyjna gospodarka zajmuje 6 i 8 miejsce na świecie pod względem odpowiednio wartości wytworzonego produktu krajowego brutto (2,49 bln USD, tj. ok. 39 tys. USD per capita w 2012 r.) i wartości parytetu siły nabywczej (2,39 bln USD, tj. ok. 37 tys. USD per capita w 2012 r.) (IMF, 2015, Report... UK). O jej pozycji politycznej decyduje członkostwo w najważniejszych strukturach europejskich (tj. UE i Radzie Europy), atlantyckich (tj. NATO i OECD) oraz światowych (tj. G8, G20, WTO i Wspólnocie Narodów), a także status stałego członka Rady Bezpieczeństwa ONZ. Ze względu na stacjonowanie wojsk brytyjskich w ok. 80 państwach świata oraz utrzymywanie arsenału nuklearnego (obejmującego obecnie ok. 200 głowic) wydatki ponoszone przez Wielką Brytanię na cele militarne (które wynosiły 62,7 mld USD w 2011 r.) są mniejsze jedynie od wydatków Stanów Zjednoczonych, Chin i Rosji (SIPRI, 2015). Tymczasem Kosowo zamieszkuje zaledwie ok. 1,7 mln ludności (wg szacunków z 2011 r.) (Enti i Statistikës së Kosovës, 2011), której obecna struktura etniczna wykrystalizowała się dopiero po emigracji kilkuset tysięcy Serbów i Cyganów w połowie ubiegłej dekady. Wartość wytworzonego produktu krajowego brutto (6,49 mld USD, tj. 3,8 tys. USD per capita w 2011 r.) (IMF, 2014, Report...) oraz parytetu siły nabywczej (14,50 mld USD, tj. 8,5 tys. USD per capita w 2013 r.) (IMF, 2015, Report... Kosovo) daje gospodarce kosowskiej 144 miejsce wśród innych gospodarek narodowych. $\mathrm{Na}$ płaszczyźnie politycznej poważnym problemem pozostaje odmowa uznania Kosowa przez znaczną część społeczności międzynarodowej (m.in. Argentynę, Brazylię, Chiny, Hiszpanię, Indie, Indonezję, Iran, Meksyk, Republikę Południowej Afryki i Rosję), co uniemożliwia temu krajowi ubieganie się o członkostwo w większości organizacji międzynarodowych. Oprócz istnienia przesłanek decydujących o obiektywnej słabości politycznej i ekonomicznej Kosowa, należy także wskazać, że nie znajduje się ono w centrum zainteresowań Wielkiej Brytanii, a wzajemne kontakty zostały nawiązane niejako przy okazji wypełniania przez Brytyjczyków „moralnego zobowiązania” nie tyle wobec konkretnej nacji, co raczej całej ludzkości. W tym kontekście zupełnie naturalne wydaje się przyjęcie przez oba państwa takiej formuły relacji, która uwzględniając indywidualne możliwości i oczekiwania każdej ze stron, przyznaje im zróżnicowane prawa i obowiązki. Paternalistyczna pozycja Wielkiej Brytanii wyraża się zatem nie tylko poprzez oddziaływanie na kierunki aktywności politycznej oraz rozwój gospodarczy i społeczny Kosowa, lecz również występowaniem w obronie inte- 
resów słabszej strony na forum organizacji międzynarodowych (w szczególności Unii Europejskiej i NATO) oraz w stosunkach z państwami trzecimi. Natomiast mieszkańcy Kosowa poprzez korzystanie z udzielanej przez Brytyjczyków na bieżąco pomocy wojskowej, politycznej i finansowej oraz udostępnienie know-how (m.in. w sferach dotyczących tworzenia, wdrażania i egzekwowania rozwiązań prawnych, podnoszenia jakości administracji publicznej, rozwijania produkcji przemysłowej i rolnej, nawiązywania kontaktów handlowych oraz implementacji rozwiązań technicznych służących ochronie środowiska i wykorzystywaniu odnawialnych źródeł energii) zaciągnęli wobec Wielkiej Brytanii dług wdzięczności, którego spłata jest tym trudniejsza, że jej termin ani warunki nie mają wymiaru formalnego, a jedynie moralny. Nawet jeżeli obecnie Kosowo nie stanowi liczącego się gracza na europejskiej scenie politycznej, to w przypadku jego wejścia do Unii Europejskiej i NATO istnieje spora szansa, że kosowscy politycy będą głosowali w tych organizacjach w sposób odpowiadający życzeniom brytyjskim. Dalekosiężna polityka Wielkiej Brytanii zmierzająca do pozyskania przyszłego sojusznika wewnątrz struktur europejskich wydaje się zatem przynosić pożądane efekty, służąc równocześnie stabilizacji i rozwojowi tej części Bałkanów Zachodnich.

\section{BibLIOGRAFIA:}

Blair, T. (2011). Podróż. Katowice: Wydawnictwo Sonia Draga.

Enti i Statistikës së Kosovës (2011). Population and Housing Census in Kosovo. Preliminary Results - June 2011. Pristina: Enti i Statistikës së Kosovës.

Foreign and Commonwealth Office (FCO) (2011). Diplomatic Influence \& Values (DIV) Fund 2011/12-2014/15. London: Foreign and Commonwealth Office.

Gołembski, F. (2011). Polityka zagraniczna Wielkiej Brytanii. Warszawa: Wydawnictwo ASPRA-JR.

Harvey, M. (2011). Perspectives on the UK's Place in the World. London: Chatham House. International Monetary Fund (IMF) (2014). Report for Selected Countries and Subjects. Kosovo. Gross domestic product, current prices.

http://www.imf.org/external/pubs/ft/weo/2011/01/weodata/weorept.aspx?sy=2008\&ey$=2011 \& \mathrm{scsm}=1 \& \mathrm{ssd}=1 \& \mathrm{sor} \mathrm{t}=$ country $\& \mathrm{ds}=. \& \mathrm{br}=1 \& \mathrm{c}=967 \& \mathrm{~s}=\mathrm{NGDPD} \% 2 \mathrm{CPP}-$ PGDP\&grp $=0 \& a=\& p r . x=34 \& p r . y=5$.

International Monetary Fund (IMF) (2015). Report for Selected Countries and Subjects. Kosovo. Gross domestic product based on purchasing-power-parity (PPP) valuation of country GDP.

http://www.imf.org/external/pubs/ft/weo/2011/01/weodata/weorept.aspx?pr.x=58\&pr.y $=17 \&$ sy $=2009 \& \mathrm{ey}=2016 \& \mathrm{scsm}=1 \& \mathrm{ssd}=1 \&$ sort $=$ country $\& \mathrm{ds}=. \& \mathrm{br}=1 \& \mathrm{c}=967 \& \mathrm{~s}=\mathrm{P}$ PPGDP\&grp $=0 \& a=$. 
Łastawski, K. (1979). Polityka zagraniczna Wielkiej Brytanii 1945-1956. Warszawa: Państwowe Wydawnictwo Naukowe.

Norton-Taylor, R. (2008). New mission for British troops in Kosovo, „The Guardian”.

Office for National Statistics (ONS) (2015). 2011 UK Census.

http://www.ons.gov.uk/ons/guide-method/census/2011/uk-census/index.html.

Pavlowitch, S.K. (2009). Historia Bałkanów (1808-1945). Warszawa: Wydawnictwo Uniwersytetu Warszawskiego.

Selimi Petrit (2014). Kosovo-British Relations.

http://www.diplomatmagazine.com/issues/2011/september/503-kosovo-british-relations-v15-503.html.

Trevelyan, G.M. (1963). Historia Anglii. Warszawa: Państwowe Wydawnictwo Naukowe; UK Government (2015). Policy promoting stability throughout the Western Balkans.

https://www.gov.uk/government/policies/promoting-stability-throughout-the-westernbalkans.

UK Government (2015). UK and Kosovo. https://www.gov.uk/government/world/ kosovo.

UNMIK Media monitoring: Kosovo Media Highlights (2011). Cameron: Dialogue, an important moment for Kosovo (Express). Pristina: UNMIK.

Zins, H. (1995). Historia Anglii. Wrocław-Warszawa-Kraków: Wydawnictwo Zakładu Narodowego im. Ossolińskich - Wydawnictwo Bellona. 